\title{
Energy Improvement District: case from Polytechnic University
}

\author{
Yury Nurulin \\ Peter the Great St.Petersburg State \\ Polytechnic University \\ St.Petersburg, Russia \\ yury.nurulin@gmail.com
}

\author{
Inga Skvortsova \\ Peter the Great St.Petersburg State \\ Polytechnic University \\ St.Petersburg, Russia \\ ingaskvor@list.ru
}

\author{
Elena Vinogradova \\ Peter the Great St.Petersburg State \\ Polytechnic University \\ St.Petersburg, Russia \\ vinogradova@spbstu.ru
}

\begin{abstract}
The study addresses to harness the full energy savings potential of existing city's structures, to elaborate holistic strategies that integrate sector-based approaches, and to engage energy consumers in strategic energy planning for energy improvement district (EID). The article presents results of a case study of Peter the Great St. Petersburg Polytechnic University campus as an EID. SPbPU is considered as a typical object, possessing properties that are inherent in a large number of territorial entities of St. Petersburg, where there are real estate objects that are in private, state and regional ownership. Using the method of identifying stakeholders, the article analyzes the stakeholders of the EID at SPbPU. The EID special characteristics are highlighted which obstruct to motivate main users on resource saving. In combination with the SWOT analysis, this allows us to identify gaps and challenges in creation of a resource-saving motivation system for the main users. Results of the study form a background for development of strategic plan for EID with close interaction of main stakeholders. Invariant components of the case study that are of interest for other EID were selected and described.
\end{abstract}

Keywords-energy efficiency, stakeholders motivation, strategy energy planning

\section{INTRODUCTION}

"On average, every $€ 1$ invested in energy efficiency saves $€ 3$, over the lifespan of a technology" [1]. Various versions of similar statements can be found everywhere, ranging from advertising brochures to serious analytical studies. They reflect the unanimous expert opinion about the prospects of energy-saving technologies, and at the same time indicate the lack of tools that would allow to accurately calculate the economic effect from the energy-saving measures. The reason for this is not a lack of research in the area of energy production, transfer and use, but rather the complexity and versatility of the problems that form potential for energy saving. Energy consumption in the residential sector is implemented in the framework of complex systems that belong to the class of socio-technical systems, and have technical, economical and social subsystems.

The technical components of the system are equipment and technologies that ensure the supply and metering of energy consumption by end users. From the point of view of energy saving, the objective function of this subsystem is to minimize energy losses during its transfer from the power generator to the consumer. The necessary conditions are the requirement to ensure the transfer of energy in the mode of peak consumption and average loads.
The economic components of the system are financial and organizational mechanisms that stimulate (or vice versa, impede) the consumption of various types of energy resources in the context of consumption volumes, time and spatial frameworks of energy consumption by end users. From the point of view of energy saving, the objective function of this subsystem is to stimulate minimization of energy consumption. A necessary condition for the effective functioning of this subsystem is the compliance of the general level of financial burden on the energy consumer with the general level of economic development and financial condition of energy end users. Too high tariffs or financial restrictions on the use of resources can serve as a barrier to the development of the economy or worsen the quality of life of the consumer (the greatest energy savings will be achieved if you refuse to use any electrical appliances due to the high cost of electricity). On the contrary, a financial burden of $0,5-1 \%$ is unlikely to serve as an effective economic incentive to save energy consumption.

The social components of the system reflect the behavioral characteristics of the energy resources end-users. They are significantly affected by financial and economic mechanisms that regulate energy consumption. However, issues of end-user behavior cannot be reduced only to the issues of tariff optimization for consumed energy. Obviously, in order to optimize the activities of this subsystem, it is necessary to maximally activate non-economic energy stimulation mechanisms that could be considered as the objective function of this subsystem.

The above shows that to obtain the maximum effect from energy-saving measures, a systematic approach is needed based on a comprehensive analysis of all the components of the socio-technical system of energy saving.

\section{LITERATURE REVIEW}

Cities and urban areas with their vast building stock and infrastructure play a key role in reaching European energy efficiency targets. They represent crucial spaces with great energy efficiency potential. Nevertheless, transition towards high energy efficiency cities is often hampered by sectoral fragmentation and lack of cooperation between public authorities, energy utilities and property owners. Currently, a number of project initiatives aimed at a comprehensive solution to the problem of improving energy efficiency is implementing all over the world including Europe. Different aspects of energy saving problems including in housing and infrastructure sectors are studied in these projects. 


\section{A. Innovation technologies for energy saving in housing}

The main content of researches devoted to technical aspects of energy saving is renewable energy and corresponding technologies. [2]. Progress that was made in recent years in the field of digitization, renewable energy and electrical energy storage provides an opportunity to increase energy and economic efficiency in all areas of activities. All experts point out that at the moment, renewable energy shows the highest growth rates among all energy carriers. While a general increase in energy demand is forecasted at the level of $47 \%$ by 2040 , the consumption of renewable energy sources (RES) will increase by $93 \%$ at the same period [3]. The main trend in development of renewable energy technologies is reducing costs while increasing capacity and reliability of solar and wind generators [4]. According to BNEF there has been $28,5 \%$ drop in the price for crystalline - silicon PV modules for every doubling of cumulative capacity since 1976 [5].

The rapid growth in the number of RES innovative projects brings to the fore the tasks associated with the need for power redundancy and energy storage to ensure the flexibility of the power system at times of peak loads. In addition to the known problem of daily irregularity of electricity production at renewable energy facilities, it should be noted the seasonal component, which is manifested in connection with changes in the intensity of solar radiation and wind energy at different times of the year. Because of this, the average monthly power consumption may vary by several times. Since the system must be designed for stable operation at peak times, in fact this causes additional hidden investment costs, which are often not taken into account when comparing the costs of generating electricity from different sources. Batteries that are needed to replenish energy in dark or calm weather have become one of the limiting factors for increasing the efficiency of renewable energy. Their production and disposal can have a negative impact on the environment, and the limited service life and the need for replacement cause additional costs during the operation of renewable energy sources.

The efficiency of batteries increases, and the price decreases due to the development of technology and growing demand. Both renewable energy sources and electric vehicles have a significant impact on this process, where batteries are also one of the key elements. BNEF expects that sales of electric vehicles will increase from 1.1 million currently, to 30 million by 2030 , which will lead to a decrease in the basic cost of batteries [6].

One of perspective innovations for increase of efficiency of RES is development of semiconductor devices with wide bandgap (WBG) technologies that is stimulated by the demand for highly efficient power electronics devices, which are most used in electric drives, connection of renewable energy sources (RES) and "smart home" energy devices [7].

Strictly speaking, the above technical tasks for improving the production technologies for RES are only indirectly related to the housing sector. Traditionally, in the centralized energy supply systems, energy production is a part of industrial sector. The housing and utilities sector consumes energy resources and it doesn't matter who and how produces energy. The main thing is the volume, price and reliability of supply. RES development changes the situation and energy generators come to housing sector and become a part of housing infrastructure. Solar energy, wood and wind are the most widely used RES: wood is used as fuel for district heating, both centralized and local, and for the heating of individual buildings. All the most of the electricity generated by local communities and located in urban areas comes from renewable and environmentally friendly energy sources, whereas the remaining electricity is generated by combined heat and power plants working in cogeneration mode.

Transition to decentralized energy supply system provides a number of advantages but formulates additional questions for economical and social subsystems of the complex energy saving system.

\section{B. Business support mechanisms for RES development}

The economic attractiveness of renewable energy is in the analysis of many experts. While some experts state that "renewables are reaching price and performance parity on the grid and at the socket" [8], another underline that high rates of growth in production of renewable energy are largely due to significant state support [9].

Energy efficiency projects are not typical investments: they do not result in direct revenues but rather in nonexpenses, i.e. through savings of energy, water and other resources. To transform the effect of energy saving projects from the material and technical to the financial sector, appropriate tools are necessary. Such tools are studied in the BSR INTERREG project EFFECT4buildings develops [10]. In collaboration with public property owners and managers, financial tools and methods that help improve profitability, facilitate the financing of energy investments and reduce risks are analyzed. As examples of such tools, financial calculation instruments, bundling and funding tools, energy service and green leasing contracts and economic models for both producing and consuming energy are studied. Financial tools and methods are developed along a number of real cases among institutions participating in the project.

\section{Social aspects of energy saving measures}

The importance of social aspects for the energy efficiency problem solving is confirmed by many publications. These questions are in the focus of a numerous of BSR INTERREG projects. Two Interreg projects, AREA 21 and LowTEMP, unlock energy efficiency potential by triggering public and private strategic partnerships for energy production and management and by offering low temperature district heating technology for more efficient heating systems [11].

The following aspects of social questions are studied [12].

1. Organizational structure of social innovations for energy saving. Main focus of these studies is related to consumer/producer associations and cooperatives for energy saving. A significant share of these cooperatives are organized in well-structured networks that bring together citizens towards joint ownership and participation in renewable energy or energy efficiency projects.

2. Measures to ensure comfortable living conditions in the context of energy shortages. Today, energy poverty still affects several million households in Europe, where residents are trying to provide adequate heating, live and pay utility bills in a timely manner in homes that are not protected from moisture and mold. This situation is significantly dependent 
on the geographical location and social status of energy resources consumers, which leads to different levels of access to possible levels of energy supply and modern technologies.

3. Social aspects of financial schemes for energy involving citizen investment:

- shareholding participation in energy communities;

- crowdfunding initiatives in the sectors of renewable energy and energy efficiency;

- citizens which finance and implement innovation projects in the field of RES;

- allocation of public resources via vouchers or grants and

- donations of business-angels, i.e. citizens voluntarily providing financial support to an energy efficiency without expecting any return.

4. Educational aspects, referring to raising awareness and contributing to increasing the acceptance of renewable energy and energy efficiency measures and projects. This mode of social innovation can explore synergies with cultural and entertainment activities addressing general messages such as climate change mitigation and the environment protection. Additional possibility for involvement of the youth in energy saving measures provide ICT gaming technology.

\section{Methodology}

A systematic approach to analysis of the complex problem of strategic planning of energy saving measures at the level of the urban districts was proposed in the framework of the AREA 21 project [13]. The project is based on 2 keystones:

- the concept of an Energy Improvement District (EID) as a limited area where both consumers and producers or suppliers of energy resources consumed by the housing sector are compactly located and

- the comparative analysis of 7 pilot areas located in different countries Baltic Sea region.

The selection of EID is based on the set of criteria developed by the project Partners (figure1). The process of defining the EID starts from selection the pilot area which corresponds to these criteria. In order to provide comparable data for analysis of various EIDs, the project has developed a method for collecting and analyzing information, consisting of five steps as it is shown in Figure 2.

First step of the above method is aimed on analysis of external environment of the EID. It provides data on opportunities and threats for the SWOT analysis which will be done at the Step 3.

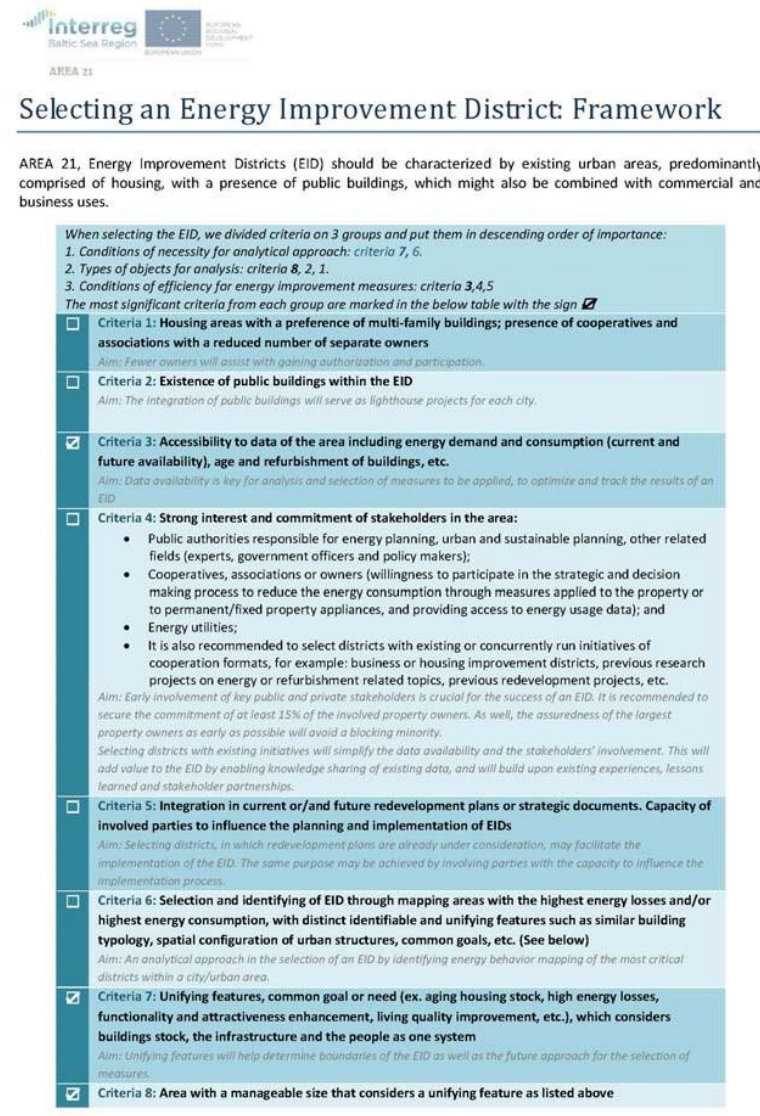

Fig. 1. Criteria for the EID selection 


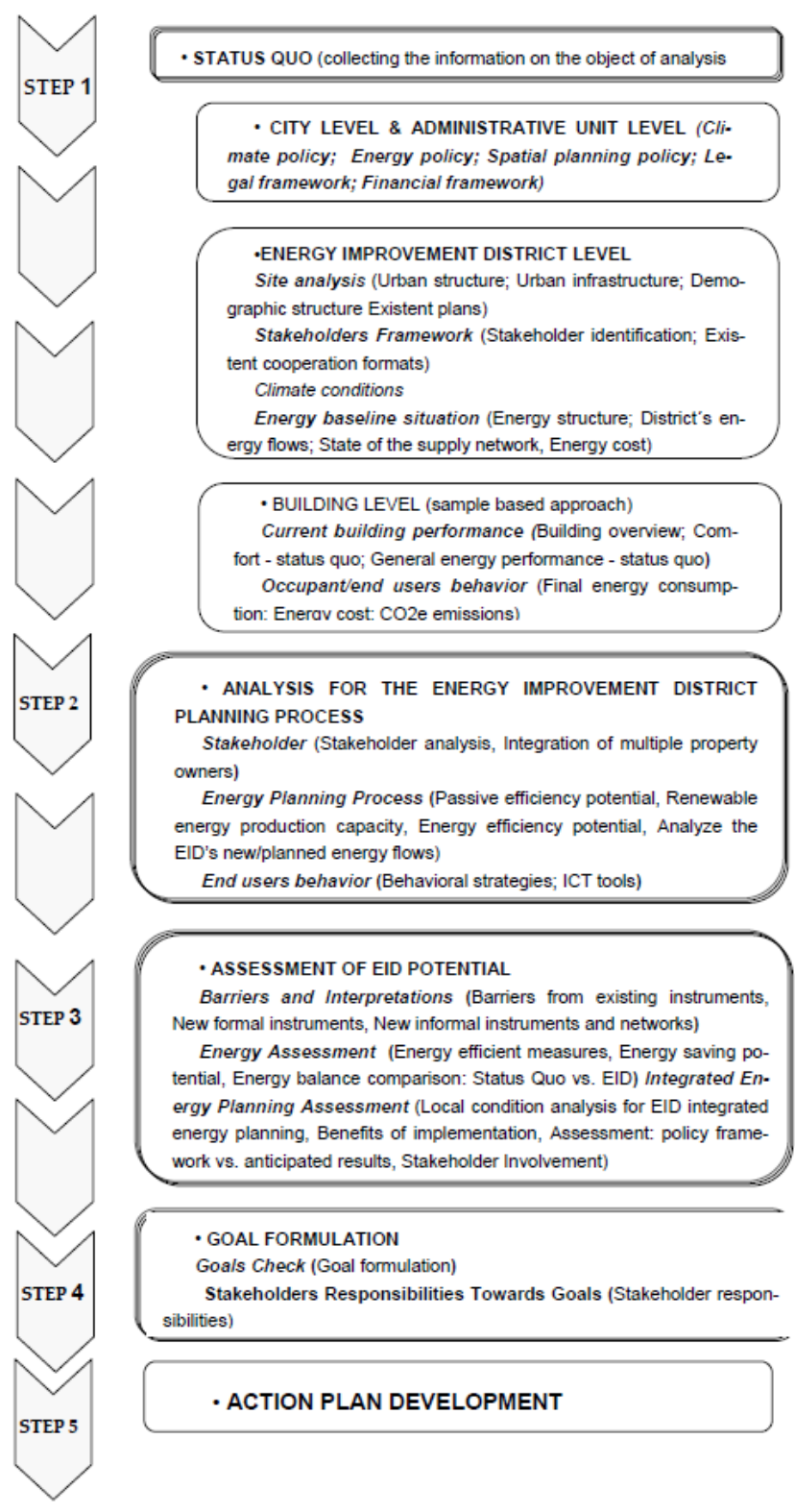

Fig.2 Steps for analyzing of Energy Improvement District

Second step provides necessary input to defining strengths and weakness of analyzed EID from the point of view of energy efficiency. Standard SWOT procedures realized at the Step 3 provide formulation of goals and development of action plan to achieve these goals (steps 4 and 5). Since the social aspects of energy saving are considered as one of the main focus area of AREA21 project, the analysis of stakeholders involved in strategy energy planning at the district level is one of key tasks. To solve this task, the Stakeholder Map as special instrument for visualization of stakeholders roles was developed according to their main intervention in the life cycle of an EID, as primary or secondary stakeholders [14].

The following Intervention Categories in the EID life cycle were selected as main elements of Stakeholder Map [15]:

\section{Category 1: Strategic Policy Development}

This category comprises energy sector policy making on environmental protection and spatial planning to promote EID goals and development. It has a strategic focus by identifying needs of stakeholders and using stakeholder consultation to review, evaluate and monitor the policy to make further improvements.

\section{Category 2: Regulation and Financing}

This category comprises practical rules for everyday working in the fields of energy, environmental protection and spatial planning, as well as financing models for EID development. Financing includes private investments, incentives and other funding programs.

\section{Category 3: Cooperative Energy Planning}

This category includes the communications that will be undertaken with EID stakeholders including notification of project updates and cooperative formats such as round table discussions and online forums. The communication material will address all matters related to energy planning for the EID.

\section{Category 4: Implementation}

This category includes the necessary technology delivery and energy supply for the EID, as well as the people and organizations implementing the EID.

\section{Category 5: End Use, Management \& Maintenance}

This category involves end users such as beneficiaries and users of the EID, as well as the groups responsible for management and maintenance of the EID.

\section{RESULTS AND DISCUSSION}

\section{A. EID selection}

One of the AREA21 project pilot areas is the EID Polytechnic which is the main subject for further analysis on the base on the above methods [16].

EID Polytechnic is located at the north part of SaintPetersburg in Kalininskiy district, Academichesky municipality. Local territorial context of EID Polytechnic is shown at the figure 3 .

The EID was selected as a result of analysis of different areas of Saint-Petersburg on the base of selection criteria presented at figure.1. The following criteria were considered as the most important for the selection (are marked by $\square$ at the figure 1).

Criteria 7: Unifying features, common goal or need (ex. aging housing stock, high energy losses, functionality and attractiveness enhancement, living quality improvement, etc.), which considers buildings stock, the infrastructure and the people as one system.

The following technical subsystems play key role for the energy efficiency in Polytechnic.

Electricity supply subsystem

No electricity generators, electricity supply from the city, small solar and wind generators used only for testing and research. Centralized electricity supply: 24 electricity transformer substations, 42 transformers, 31 of them are more than 45 years old while life time is $20-25$ years. Cable lines $6 \mathrm{kV}$ with the length around $25 \mathrm{~km}, 90 \%$ of which have average exploitation age more than 45 years. Cable lines 
$0,3 \mathrm{kV}$ with the length around $50 \mathrm{~km}, 90 \%$ of which have average exploitation age more than 45 years.

Energy Baseline Situation: heat and water supply subsystem

The length of external serviced heating networks is $20 \mathrm{~km}$. The length of outdoor networks of drinking and fire water supply and sewerage systems is $30 \mathrm{~km}$. The length of internal heat supply, water supply and sewerage systems more than $150 \mathrm{~km}$. The number of heat nodes and water-measuring units more than 140 . The number of sewer and water wells more than $800.80 \%$ of all external and internal water and supply and sewerage systems have physical wear or exceeded service life. Combination of centralized and decentralized systems.

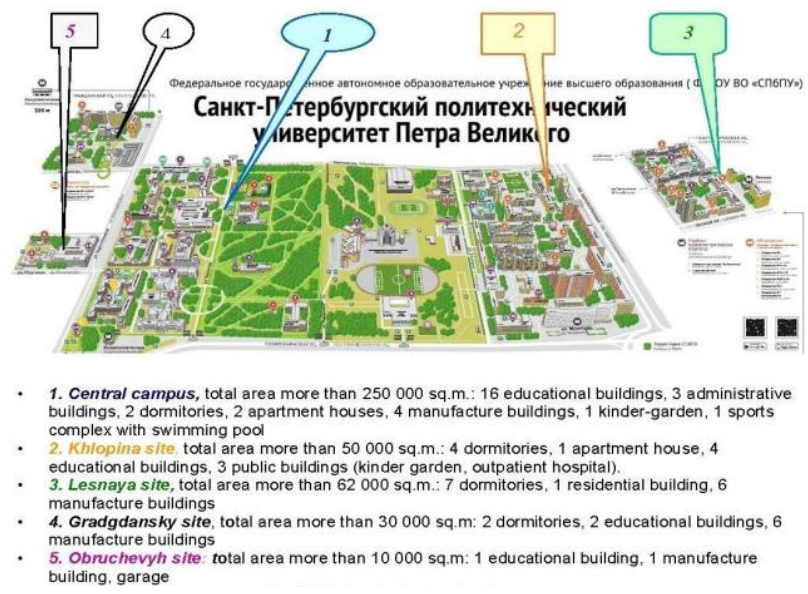

Fig. 3. EID Polytechnic: territorial aspects

The heat supply of buildings on the Central Campus is provided by the Central Boiler House with the thermal capacity $26 \mathrm{Gcal} / \mathrm{h}$ and the pressure of the coolant in the pipes at the output 4-4.5 bar.

Heat supply of buildings on the Lesnaya site is provided by the Campus Boiler with the thermal capacity $6.5 \mathrm{Gcal} / \mathrm{h}$ and the pressure of the coolant in the pipes at the output 4.5-5 bar.

Heat supply of buildings on the Khlopinskaya site is provided from urban networks. The pressure of the coolant in the pipes is 5.05 .5 bar.

The responsibility on maintenance and use these energy supply subsystems lies on a single juridical person - Peter the Great Saint-Petersburg Polytechnic University (SPbPU) that make it natural to consider different technical elements of the infrastructure of supply energy resources in Polytechnic as subsystems of one energy resources supply system. The technical condition of this system elements creates the most dangerous threats for achievement of EID goals.
Criteria 3: Accessibility to data of the area including energy demand and consumption (current and future availability), age and refurbishment of buildings, etc.

The availability of data is one of prerequisite for analysis. Data of energy consumption refer to the category of personal, which in some cases creates additional barriers to their receipt. The centralized management system in the EID Polytechnic greatly simplifies the task of obtaining energy consumption data for EID analysis.

Criteria 5: Integration in current or/and future redevelopment plans or strategic documents. Capacity of involved parties to influence the planning and implementation of EIDs

Conducted analysis has showed the presence in St. Petersburg of a sufficiently developed regulatory framework of the federal and regional levels on energy efficiency and energy saving in housing. SPbPU develops and realizes own programs for renovation and development of outdoor infrastructure and indoor equipment for energy resources supply of buildings in the campus.

All of the above confirms that the SPbPU camp meets the selection criteria for EID developed under the AREA21 framework.

\section{B. EID analysis}

Following the methodology presented at figure 2, SWOT analysis of EID Polytechnic was conducted (see figure 4). Results of this analysis were discussed at 3 Local Stakeholders Workshops that were organized in SPbPU with methodical support of AREA21 Partners. One of the key factors for the success of these workshops was the informed choice of their participants. This choice was made using EID Polytechnic Stakeholder Map (see figure 5). Social aspects of energy saving measures were selected as priority topics for energy saving in SPbPU and the motivation in energy saving for different stakeholders was discussed. Summarized results of these discussions are given in the table 1 . Since the most of stakeholders in EID Polytechnic do not have direct economical motivation in energy saving, to realize EID goals it is necessary to stress opinion at behavioral aspects and to provide measure which will develop the internal motivation of SPbPU students and employees in energy saving when they use $\mathrm{SPbPU}$ facilities and infrastructure.

The result of the analysis and discussion was an action plan that contains a list of tasks to be solved to achieve the goals of the EID (see figure 6). Since this action plan was developed in cooperation with all parties which will be involved in its realization, prospects for its implementation significantly increased. 


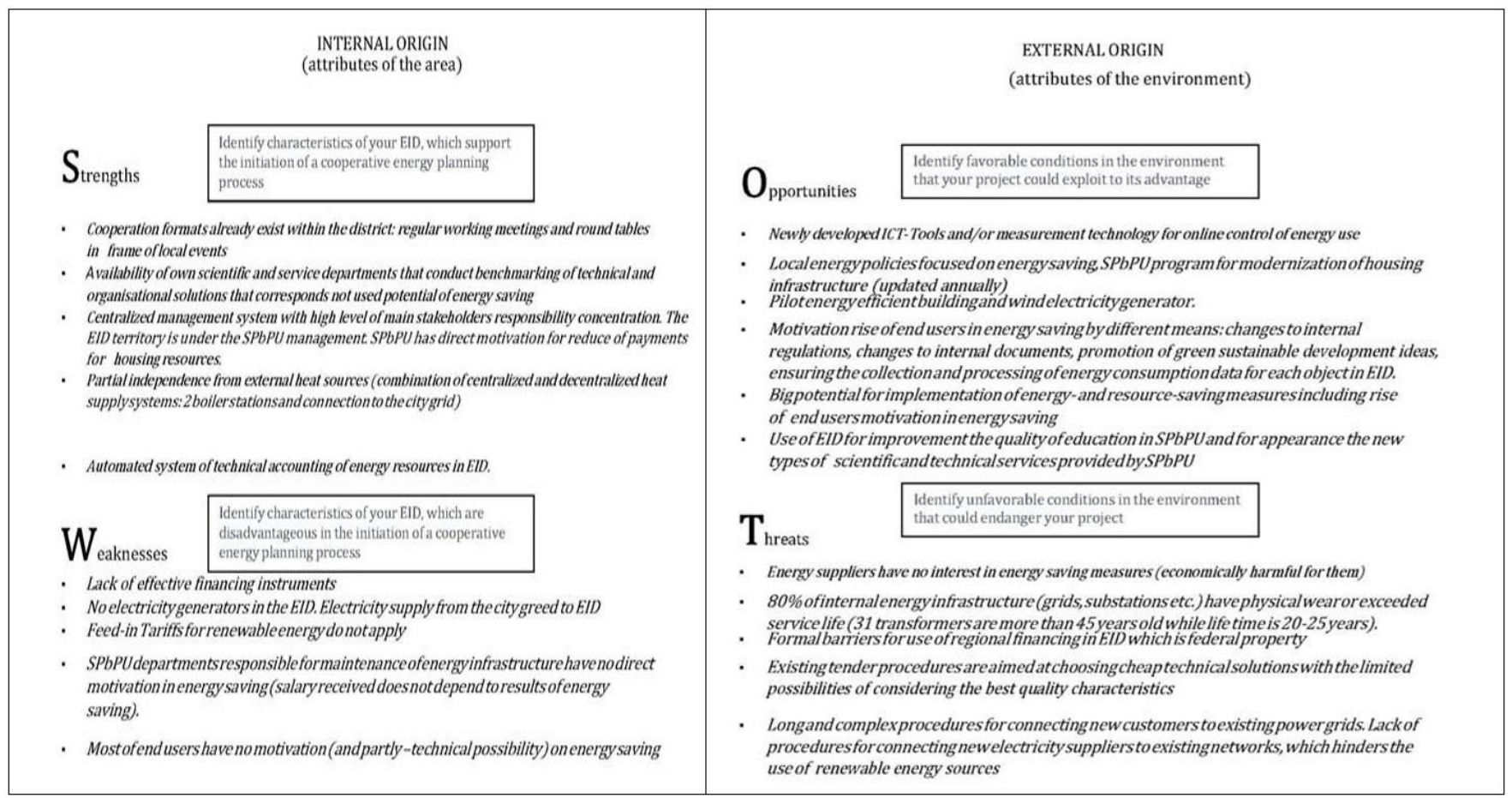

Fig. 4. SWOT-analysis of EID Polytechnic

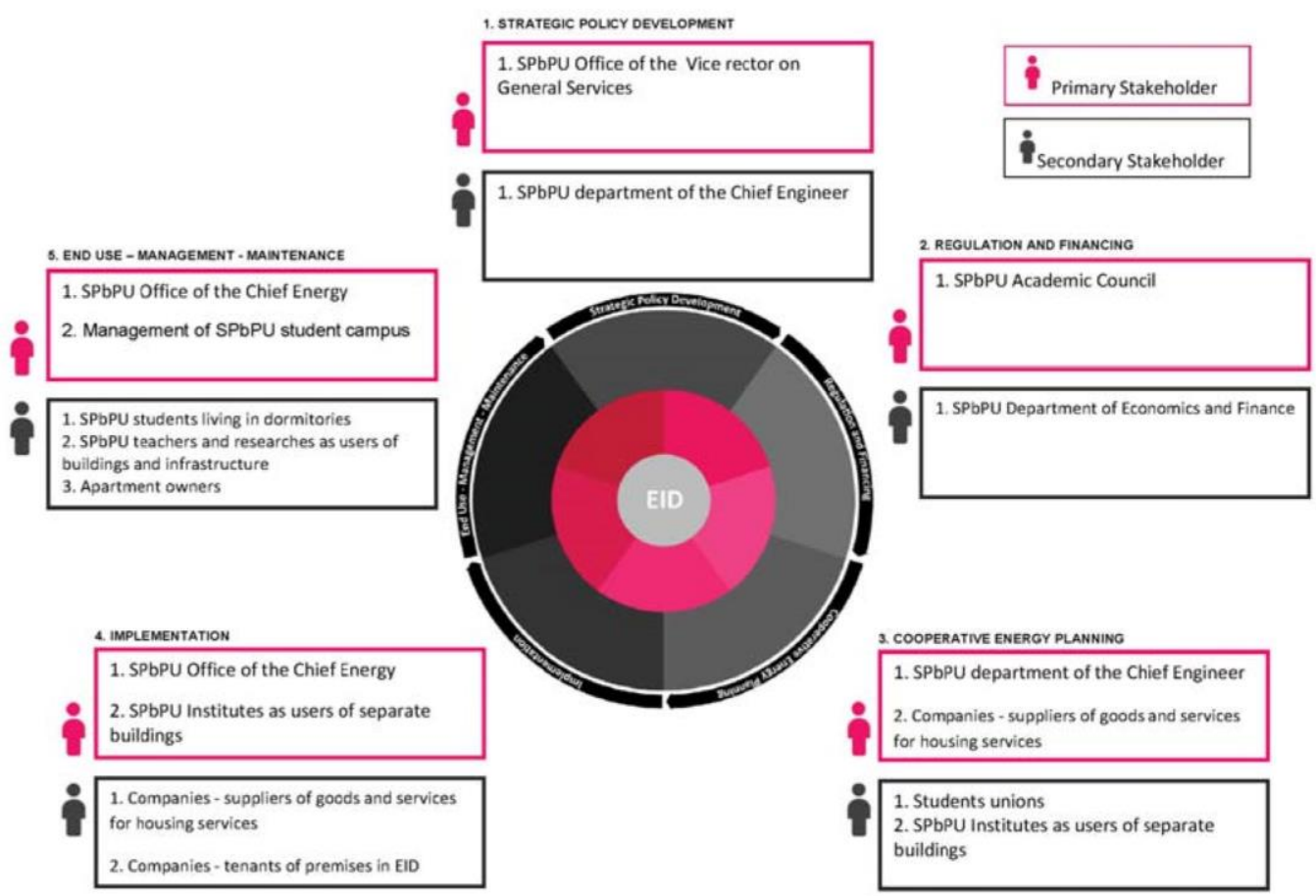

Fig. 5. Stakeholder Map of EID Polytechnic 
TABLE I. ANALYSIS OF STAKEHOLDERS MOTIVATION

\begin{tabular}{|c|c|c|c|c|c|}
\hline & Stakeholder & $\begin{array}{l}\text { Degree of interest } \\
\text { in energy saving }\end{array}$ & $\begin{array}{l}\text { Potential to in- } \\
\text { crease the interest } \\
\text { in energy saving }\end{array}$ & $\begin{array}{l}\text { The possibilities of } \\
\text { influencing the fi- } \\
\text { nal result }\end{array}$ & $\begin{array}{l}\text { Main problems within the } \\
\text { framework of existing } \\
\text { opportunities }\end{array}$ \\
\hline 1 & $\begin{array}{l}\text { Managers of } \\
\text { the object }\end{array}$ & $\begin{array}{l}\text { Direct interest in } \\
\text { frame of the job re- } \\
\text { sponsibilities }\end{array}$ & $\begin{array}{l}\text { Finalization of } \\
\text { job descriptions, tar- } \\
\text { gets and their moni- } \\
\text { toring with bonuses } \\
\text { based on the results } \\
\text { in energy saving.. }\end{array}$ & $\begin{array}{l}\text { High } \\
\text { (development of } \\
\text { technical aspects, } \\
\text { increase of the work } \\
\text { efficiency) }\end{array}$ & $\begin{array}{l}\text { Absence of direct links be- } \\
\text { tween salary and saved } \\
\text { money thanks to energy } \\
\text { saving measures. Insuffi- } \\
\text { cient capacity to analyze } \\
\text { resources consumption in } \\
\text { separate buildings }\end{array}$ \\
\hline 2 & $\begin{array}{l}\text { Apartment } \\
\text { owners }\end{array}$ & $\begin{array}{l}\text { Direct interest } \\
\text { (costs saving, qual- } \\
\text { ity of life) }\end{array}$ & $\begin{array}{l}\text { Additional infor- } \\
\text { mation on existing } \\
\text { opportunities }\end{array}$ & $\begin{array}{l}\text { Relatively small } \\
\text { (their number in the } \\
\text { EAD Polytech- } \\
\text { nichesky is insig- } \\
\text { nificant) }\end{array}$ & $\begin{array}{l}\text { Lack of technical capacity } \\
\text { to regulate heat consump- } \\
\text { tion in the old apartments }\end{array}$ \\
\hline \multirow[t]{2}{*}{3} & $\begin{array}{l}\text { SPbPU } \\
\text { teachers and } \\
\text { researches as } \\
\text { users of } \\
\text { buildings and } \\
\text { infrastructure }\end{array}$ & $\begin{array}{l}\text { Indirect interest, } \\
\text { (practically absent, } \\
\text { only quality of } \\
\text { conditions for the } \\
\text { work) }\end{array}$ & $\begin{array}{l}\text { Stimulation of } \\
\text { SPbPU units for sav- } \\
\text { ing of resources } \\
\text { (water, heat, elec- } \\
\text { tricity) }\end{array}$ & $\begin{array}{l}\text { Practically absent, } \\
\text { although they are } \\
\text { end users for most } \\
\text { of consumed re- } \\
\text { sources (more than } \\
40 \text { buildings) }\end{array}$ & $\begin{array}{l}\text { Lack of technical capacity } \\
\text { to regulate heat consump- } \\
\text { tion in the old buildings. } \\
\text { Inability to collect data on } \\
\text { resources consumed by the } \\
\text { unit }\end{array}$ \\
\hline & Stakeholder & $\begin{array}{l}\text { Degree of interest } \\
\text { energy saving }\end{array}$ & $\begin{array}{l}\text { Potential to in- } \\
\text { crease the interest in } \\
\text { energy saving }\end{array}$ & $\begin{array}{l}\text { The possibilities } \\
\text { influencing the } \\
\text { nal result }\end{array}$ & $\begin{array}{ll}\text { of } & \text { Main problems } \\
\text { fi- } & \text { within the frame- } \\
& \text { work of existing } \\
& \text { opportunities }\end{array}$ \\
\hline 4 & $\begin{array}{l}\text { SPbPU stu- } \\
\text { dents as us- } \\
\text { ers of build- } \\
\text { ings and } \\
\text { infrastructure }\end{array}$ & $\begin{array}{l}\text { Indirect interest, (pra } \\
\text { tically absent, on } \\
\text { quality of conditio } \\
\text { for the study) }\end{array}$ & $\begin{array}{l}\text { ac- } \text { Additional infor } \\
\text { aly mation, promotion } \\
\text { ons involvement in pro } \\
\text { jects on energy sav } \\
\text { ing }\end{array}$ & $\begin{array}{l}\text { At the moment p } \\
\text { tically absent } \\
\text { though they are } \\
\text { users for most } \\
\text { consumed resoul } \\
\text { (more than } 20 \text { bu } \\
\text { ings) }\end{array}$ & $\begin{array}{l}\text { Absence of the in- } \\
\text { formation on } \mathrm{SPbPU} \\
\text { plans and actions for } \\
\text { energy saving }\end{array}$ \\
\hline 5 & $\begin{array}{l}\text { SPbPU stu- } \\
\text { dents living } \\
\text { in dormito- } \\
\text { ries }\end{array}$ & $\begin{array}{l}\text { Indirect interest, (th } \\
\text { pay on tariffs, but } 1 \\
\text { for consumed } \\
\text { sources) }\end{array}$ & $\begin{array}{l}\text { Additional infor } \\
\text { not mation, promotion } \\
\text { re- involvement in pro- } \\
\text { jects on energy sav- } \\
\text { ing }\end{array}$ & $\begin{array}{l}\text { At the moment } \mathrm{p} \\
\text { tically absent } \\
\text { though they are } \\
\text { users of consul } \\
\text { resources in } \\
\text { dormitories }\end{array}$ & $\begin{array}{l}\text { Absence of possibil- } \\
\text { ity to collect data on } \\
\text { consumed resources }\end{array}$ \\
\hline 5 & $\begin{array}{l}\text { Companies - } \\
\text { suppliers of } \\
\text { goods and } \\
\text { services }\end{array}$ & $\begin{array}{l}\text { Direct interest (bu } \\
\text { ness) }\end{array}$ & $\begin{array}{l}\text { Long-term part- } \\
\text { nership and projects }\end{array}$ & $\begin{array}{l}\text { High (quality } \\
\text { products and } \\
\text { vices for energy } \\
\text { ing) }\end{array}$ & $\begin{array}{ll}\text { of } & \text { Restrictions of con- } \\
\text { er- } & \text { tracting system } \\
\text { av- } & \end{array}$ \\
\hline
\end{tabular}




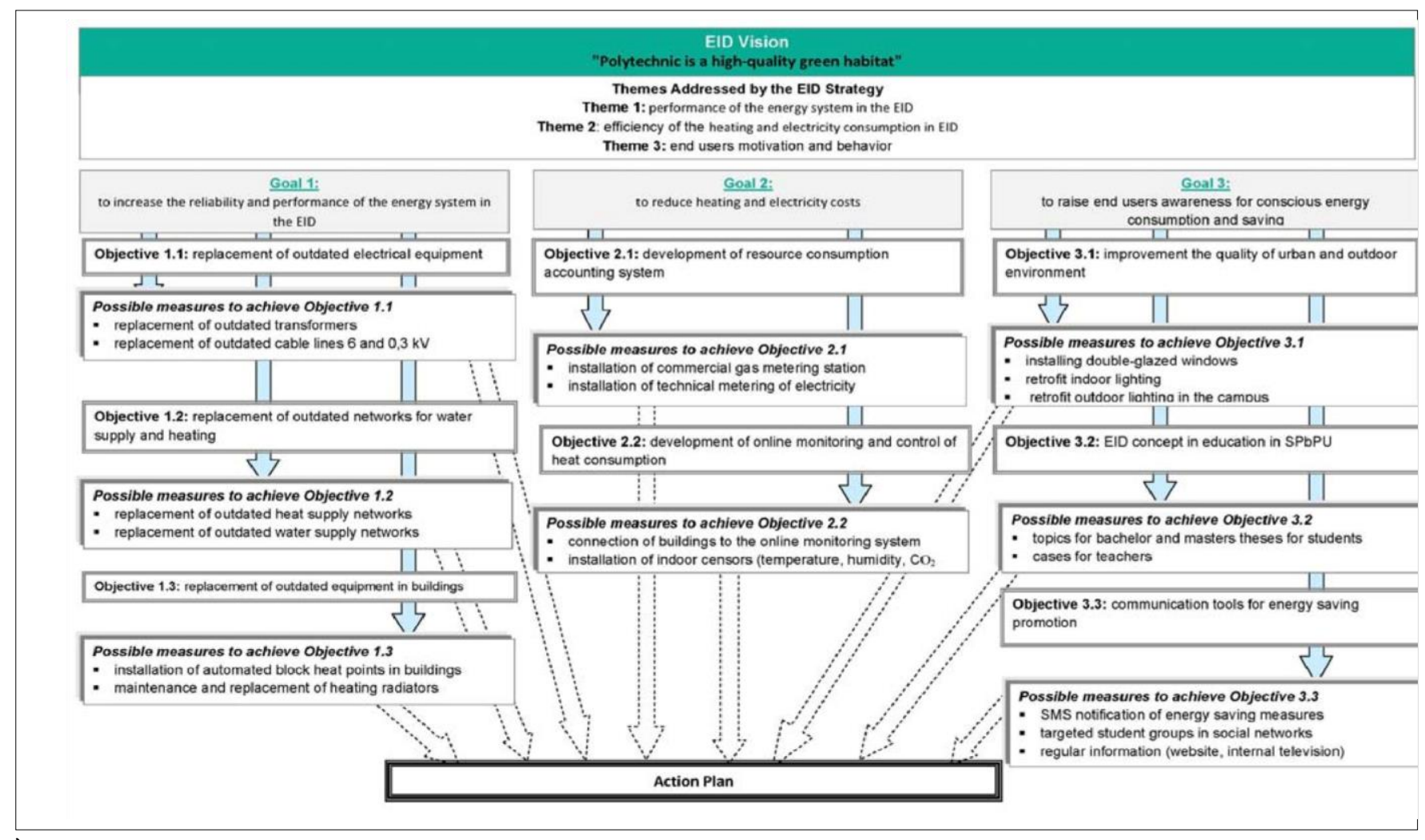

Fig. 6. EID Polytechnic: from vision to action

\section{CONCLUSION}

1. By their nature, energy saving is a complex problem, which requires the joint consideration of technical, organizational, economical, and socio-psychological problems. e

2. The EID concept developed in frame of AREA21 project provides systematic view on complex problems of energy saving in urban regions. This provides additional impetus for engaging all stakeholders in energy saving planning and realization.

2. Behavioral aspects of stakeholders are crucial for energy saving especially in cases where stakeholders have no direct economic motivation.

3. ICT and education should be considered as effective tools to promote and motivate energy saving measures.

\section{ACKNOWLEDGEMENT}

The article is prepared in the frame and with financial support of the AREA 21 project of the BSR INTERREG program.

\section{REFERENCES}

[1] M.Frassony. The biggest innovation in energy is efficiency. Available online:http://www.europeanenergyinnovation.eu/OnlinePublication/S ummer 2019/mobile/index.html\#p=16 Accessed 08 July 2019

[2] REN21. (2018) Renewables 2018 Global Status Report. Available online: http://www.ren21.net/gsr-2018/ (accessed on 08 July 2019)
[3] Makarov A.A., Grigoriev L.M., Mitrova T.A. (eds.) Prognoz razvitiya energetiki mira i Rossii. M. INEI RAN pri pravitelstve RF, 2016.-200

[4] Jäger-Waldau, A. (2018) Rooftop PV and self consumption of electricity in Europe Benefits for the climate and local economies. EEI, $3,16-20$

[5] Cheung, A. (2018) Power Markets Today. BNEF.

[6] Bloomberg New Energy Outlook 2018 Available online: https://bnef.turtl.co/story/neo2018?src=pressrelease\&utm_source=pre ssrelease Accessed 08 July 2019)

[7] Power Electronics for Green Energy Efficiency. Factors and regulations influencing the market uptake of advanced power electronics solutions Available online: https://balticgreenpower.eu/wpcontent/uploads/2019/05/GreenPE_Regional_Roadmap_web.pdf. Accessed 08 July 2019

[8] Motyka, M., Slaughter, A., Amon, C. Global renewable energy trends 2018 Available online: https://www2.deloitte.com/insights/us/en/industry/powerandutilities/global-renewable-energy-trends.html. Accessed 08 July 2019

[9] Islam, S. (2018) Key European Solar Markets Trends from the Installers' Perspective EEI, 3, 24-25

[10] Effective Financing Tools for implementing Energy Efficiency in Building. Available online: https://projects.interregbaltic.eu/projects/effect4buildings-114.html. Accessed 08 July 2019 ,

[11] https://www.interreg-baltic.eu/about-projects.html Accessed 08 July 2019

[12] J.G.Prieto. Social innovation in energy, implications for Smart Specialisation. Available online: http://www.europeanenergyinnovation.eu/Portals/0/publications/Euro peanEnergyInnovation-Winter2018.pdf. Accessed 08 July 2019

[13] Baltic Smart City Areas for the 21st Century https://area21project.eu/about/overview/

[14] Reed, M., Graves, A., Dandy, N., Posthumus, H., Hubacek, K., Morris, J., Prell, C., Quinn, C., and Stronger, L. 2009. Who's in and why? A 
typology stakeholder analysis methods for natural resource management. Journal of Environmental Management. Journal of Environmental Management 90, 1933 - 1949. Doi: 10.1016/j.jenvman.2009.01.001

[15] Z.R.Castillejos, G.Vladova, M. Hannes, J. Marcks Motyka, M. Analyzing Stakeholders for Energy Improvement Districts:
Framework. Available online: https://area21-project.eu/ Accessed 08 July 2019

[16] St. Petersburg: Energy Improvement District Polytechnic Available online: https://area21-project.eu/pilot-areas/st-petersburg/ Accessed 08 July 2019 